\title{
PENGATURAN PERLINDUNGAN HUKUM BAGI TENAGA KERJA WANITA BESERTA KELUARGANYA BERDASARKAN UU NO. 6 TAHUN 2012 TENTANG PENGESAHAN KONVENSI INTERNASIONAL PERLINDUNGAN BURUH MIGRAN BESERTA KELUARGANYA
}

\author{
Any Suryani H. ${ }^{1}$ \\ * Peneliti Hukum Ketenagakerjaan Bagian Hukum Perdata Fakulatas Hukum Universitas \\ Mataram \\ Korespondensi: k_sarkawi@yahoo.co.id \\ Naskah dikirim: 9 Mei 2016 \\ Naskah diterima untuk diterbitkan: 7 Juni 2016
}

\begin{abstract}
This study aims to assess and analyze the normative regulation of legal protection for women workers and their families based on Law No.6 of 2012 on the Ratification of the International Convention on the Protection of Migrant Workers and their Families. Processing dan data analisys done by the legal logical legal reasoning systematically and coherently and then analyzed by descriptive qualitative and subsequently concluded deductively. Based on the results obtained that: Convention on the Protection ofthe Rights of All Migrant Workers and Members of Their Families (International Convention on the Protection of the Rights of All Migrant Workers and Members of Their Families, ICRMW) defines the rights of migrant workers under two headlines: human rights of all migrant workers and members of their families (Part III), and other rights of migrant workers and their family members are undocumented or legal (Part IV). Human rights apply to all migrant workers and members of their families regardless of their legal status, while other rights applicable only to migrant workers and their family members are undocumented. The Convention does not include a new set of rights exclusively for migrant workers and members of their families.
\end{abstract}

Keywords: protection, women migrant workers, ratification of the international convention

1 Tim Peneliti Hukum Ketenagakerjaan Bagian Hukum Perdata Fakulatas Hukum Universitas Mataram. 


\begin{abstract}
Abstrak
Penelitian ini bertujuan untuk mengkaji dan menganalisis secara normatif pengaturan tentang perlindungan hukum bagi tenaga kerja wanita dan keluarganya berdasarkan Undang No 6 tahun 2012 tentang Pengesahan Konvensi Internasional Tentang Perlindungan Buruh Migrant dan Keluarganya. Pengolahan dan analisis data dilakukan dengan legal reasoning yang logis sitematik dan runtut dan selanjutnya dianalisis secara deskriptip kwalitatif dan selanjutnya disimpulkan secara deduktif. Beradasarkan hasil penelitian didapat bahwa: Konvensi Perlindungan Hak-Hak Seluruh Pekerja Migran dan Anggota Keluarganya (International Convention on the Protection of the Rights of All Migrant Workers and Members of Their Families, ICRMW) mendefinisikan hak-hak pekerja migran di bawah dua tajuk utama: hak asasi seluruh pekerja migran dan anggota keluarganya (Bagian III), dan hak-hak lain pekerja migran dan anggota keluarganya yang berdokumen atau legal (Bagian IV). Hak asasi berlaku pada seluruh pekerja migran dan anggota keluarganya tanpa memandang status hukum mereka, sementara hak-hak lain berlaku hanya pada pekerja migran dan anggota keluarganya yang berdokumen. Konvensi tersebut tidak mencantumkan serangkaian hak-hak baru yang secara eksklusif bagi pekerja migran dan anggota keluarganya.
\end{abstract}

Kata kunci: perlindungan, buruh migrant perempuan, pengesahan konvensi internasional

\title{
I. Latar Belakang
}

Pasal 27 ayat (2) Undang-Undang Dasar 1945 menyatakan bahwa "Tiap-tiap warga negara berhak atas pekerjaan dan penghidupan yang layak bagi kemanusiaan". Dari pasal tersebut jelas bahwa UndangUndang Dasar 1945 menghendaki agar semua warga Negara Indonesia yang mau dan mampu bekerja dapat diberikan pekerjaan, sekaligus dengan pekerjaan itu dapat hidup seeara layak sebagai manusia.

Pencapaian tujuan yang dikehendaki oleh Pasal 27 ayat (2) UUD 1945, merupakan sesuatu hal yang berat untuk dicapai dan dilaksanakan, mengingat jumlah penduduk yang sangat banyak yang tidak diimbangi dengan perkembangan perekonomian khususnya penyediaan lapangan kerja. Migrasi tenaga kerja intemasional menjadi fenomena global dan terjadi hampir di sebagian besar negara di dunia, termasuk Indonesia. Fenomena ini terus berkembang seiring dengan pola hubungan yang terjalin antarnegara dalam berbagai dimensi. Meningkatnya hubungan antamegara pada gilirannya berpengaruh pada intensitas arus tenaga kerja dari berbagai negara. John Naisbit, pada tahun 1996 menyimpulkan bahwa era globalisasi yang sedang berproses telah meniupkan optimisme tinggi dalam bidang ekonomi melebihi masa lalu. Era ini ditandai dengan 
terbentuknya pasar tunggal dalam perekonomian dunia yang membuka lebar bagi perorangan atau kelompok. Di sisi lainnya, mobilitas sumber daya manusia demikian intensif sehingga fenomena tenaga kerja menjadi tidak terelakkan. ${ }^{2}$

Penempatan TKI di Luar negeri menjadi salah satu dampak globalisasi, permintaan pasar, minat bekerja keluar negeri serta keinginan memperbaiki kehidupan menjadi pilihan bagi masyarakat pekerja terutam kaum muda untuk memilih mengadu nasib ke luar negeri dengan menjadi TKI.. hal ini tentunya harus didukung pula oleh kebijakan perlindungan terhadap tenaga kerja yang bekerja di luar negeri.

Bekerja adalah hak setiap manusia sebagai upaya untuk menjaga dan mempertahankan derajat kemanusiaannya sebagai mahluk Tuhan YME. Penempatan yang berkembang dengan demikian pesatnya karena menyangkut persoalan kehidupan seseorang ketika memutuskan untuk mencari kerja. Kaitannya dengan hal ini, Lalu Husni mengemukakan sebagai berikut:

\section{Bidang hukum ketenagakerjaan sebelum hubungan kerja adalah bidanghukum yang berkenaan dengan kegiatan mempersiapkan calon tenagakerja sehingga memiliki keterampilan yang cukup untuk memasuki dunia kerja, termasuk upaya untuk memperoleh lowongan pekerjaan baik didalam maupun di luar negeri dan mekanisme yang harus dilalui oleh tenaga kerja sebelum mendapatkan pekerjaan. ${ }^{3}$}

Pengaturan nasional tentang penempatan tenaga kerja Indonesia ke luar negeri adalah Undang-undang No. 39 Tahun 2004 Tentang Penempatan Dan Perlindungan Tenaga Kerja Indonesia Di Luar Negeri. Tenaga kerja Indonesia di luar negeri sering dijadikan obyek perdagangan manusia, termasuk perbudakan dan kerja paksa, korban kekerasan, kesewenang-wenangan, kejahatan atas harkat dan martabat manusia serta perlakuan lain yang melanggar hak asasi manusia.

Sejalan dengan hal tersebut diatas Indonesia telah meratifikasi Convention International Labourd Organisation (ILO) melalui UUNRI No 6 Tahun 2012 tentang Perlindungan Buruh Migran Besserta Keluarganya. Dalam hal penempatan tenaga kerja Indonesia di luar negeri merupakan suatu upaya untuk mewujudkan hak dan kesempatan yang sama bagi tenaga kerja untuk memperoleh pekerjaan dan penghasilan yang layak, yang pelaksanaannya dilakukan dengan tetap memperhatikan harkat, martabat, hak asasi manusia dan perlindungan

2 Natalis Pigay, TKI dan Tuntutan Globalisasi, <http://www.nakertrans.go.id/arsip berita/naker/tkiglobalisasi.php>. Diakses pada tangga119 Juni 2015.

${ }^{3}$ Lalu Husni, "Pengantar Hukum Ketenagakerjaan Indonesia”, (Jakarta: Raja Grafindo Persada, 2000), hal. 54. 
hukum serta pemerataan kesempatan kerja dan penyediaan tenaga kerja yang sesuai dengan kebutuhan nasional.

Persoalan penempatan TKI di LN sering terjadi persolan adalah pada fase pra penempatan tenaga kerja di luar negeri, sering dimanfaatkan calo tenaga kerja untuk maksud menguntungkan diri calo sendiri, yang sering mengakibatkan calon tenaga kerja khususnya tenaga kerja wanita yang akan bekerja di luar negeri menjadi korban dengan janji berbagai kemudahan untuk dapat bekerja diluar negeri, termasuk yang melanggar prosedur serta ketentuan pemerintah, akhirnya sering memunculkan kasus tenaga kerja Indonesia ilegal. Pada fase selama penempatan sangat sering persoalan tenaga kerja Indonesia yang berada di luar negeri, mengakibatkan permasalahan yang cukup memprihatinkan berbagai pihak. Hal ini menunjukan bahwa apabila penyelesaian tenaga kerja diserahkan pada posisi tawar-menawar (bargaining position) maka pihak tenaga kerja akan berada pada posisi yang lemah. Sebagai misal, kasus kematian yang tidak wajar sampai pada kasus penganiayaan, berbagai pelecehan tenaga kerja sampai mengakibatkan adanya rencana pihak Indonesia untuk menghentikan pengiriman tenaga kerja keluar negeri oleh karena dirasakan bahwa pengiriman tenaga kerja keluar negeri akan menemui berbagai macam kendala. Pada permasalahan purna penempatan dalam mekanisme pemulangan sering terjadi bahwa disanasini tenaga kerja yang baru pulang dari luar negeri berhadapan dengan berbagai masalah keamanan dan kenyamanan diperjalanan sampai tujuan, yang sering ditandai dengan terjadinya pemerasan terhadap hasil jerih payah yang diperoleh dari luar negeri. ${ }^{4}$

Persoalan tenaga kerja wanita semakin hari semakin meningkat tidak hanya terhadap tenaga kerja wanita itu sendiri melainkan juga bagi keluarga tenaga kerja wanita yang ditinggalkan khususnya anak anak tenaga kerja wanita, kebanyakan anak-anak yang ditinggalkan oleh tenaga kerja wanita masih balita ,mereka dititipkan di orang tua ataupun kerabat mereka yang secara ekonomipun mereka sangat lemah, tidak jarang keluarga tenaga kerja wanita yang ditinggalkan mengahadapi persoalan.

BNP2TKI mencatat bahwa jumlah tenaga kerja Indonesia di luar negeri yang bekerja disektor formal tercatat 254.445 dan di sector informal 206.778, jumlah ini diluar jumlah tenaga kerja Indonesia yang berangkat secara mandiri dan tenaga kerja yang tdk terdaftar ( diluar jalur resmi). ${ }^{5}$ Tenaga Kerja Wanita (TKW) rela meninggalkan keluarganya, baik suami, anak dan orang tuanya. Suami yang sebenarnya mempunyai kewajiban untuk memenuhi kebutuhan keluarga mereka, tidak dapat mencegahnya karena suami tidak sanggup memberikan ekonomi yang cukup kepada keluarganya karena penghasilannya yang sangat tidak

${ }^{4}$ Majalah Tenaga Kerja, Sistem Penempatan Tenaga Kerja Indonesia ke Luar Negeri, Vol 37, 2009, hal. 14 .

${ }^{5}$ Ibid. 
mencukupi kebutuhan sehari-hari. Situasi ini tidak dapat dipersalahkan kepada keluarga-keluarga TKW semata.

\section{Perumusan Masalah}

Bagaimanakah pengaturan perlindungan hukum bagi tenaga kerja wanita beserta keluarganya berdasarkan UU No. 6 Tahun 2012 ttg Pengesahan Konvensi Internasional Perlindungan Buruh Migrant beserta keluarganya?

\section{Tujuan Penelitian}

Berangkat dari permasalahan diatas maka tujuan dari penelitian ini adalah: Untuk menganalisis pengaturan perlindungan hukum bagi tenaga kerja wanita beserta keluarganya berdasarkan UU No. 6 Tahun 2012 tentang Pengesahan Konvensi Internasional Perlindungan Buruh Migrant beserta keluarganya.

\section{Keutamaan/Urgensi Penelitian}

Sesuai dengan tujuan yang ingin dicapai dalam penelitian ini, maka keutamaan penelitian ini adalah memberikan kontribusi dalam merancang materi ajar dalam rangka pengajaran Mata Kuliah Hukum Ketenagakerjaan dan Hak Asasi Manusia, serta perkembangannya pada Magister Ilmu Hukum Universitas Mataram.

\section{Temuan/Inovasi}

Penelitian ini adalah merupakan penelitian hukum normative yaitu penelitian yang mengkaji asas-asas/prinsip-prinsip hukum, mengkaji norma-norma, dan konsep-konsep hukum serta mengkaji sinkronisasi aturan hukum yang teruang dalam peraturan perundang-undangan yang berlaku. Dengan demikian kajian ini akan menemukan pemikiran-pemikiran hukum yang konstruktif dan inovatif sehingga dapat memberikan konstribusi secara teoritis bagi para ilmuan maupun penentu kebijakan dalam rangka mencari, menemukan dan merumuskan cara terbaik dan bijak didalam menetukan kebijakan.hasil penelitian ini dapat dijadikan sebagai salah satu materi pokok dalam menyusun silabi pada mata kuliah Hukum ketenagakerjaan dan keimigrasian, 


\section{Tinjauan Pustaka}

\section{Landasan Teori}

\section{a. Teori Perlindungan Hukum.}

Menurut Satijipto Raharjo, Perlindungan hukum adalah memberikan pengayoman terhadap hak asasi manusia (HAM) yang dirugikan orang lain dan perlindungan itu diberikan kepada masyarakat agar dapat menikmati semua hak-hak yang diberikan oleh hukum. ${ }^{6}$

Menurut Pjillipus M. Hadjon bahwa perlindungan hukum bagi rakyat sebagai tindakan pemerintah yang bersifat preventif dan resprensif. Perlindungan Hukum yang preventif bertujuan untuk mencegah terjadinya sengketa, yang mengarahkan tindakan pemerintah bersikap hati-hati dalam pengambilan keputusan berdasarkandiskresi dan perlindungan yang resprensif bertujuan untuk mencegah terjadinya sengketa, termasuk penanganannya di lembaga peradilan. ${ }^{7}$

Menurut Lili Rasjidi dan I.B Wysa Putra bahwa hukum dapat didifungsikan untuk menghujudkan perlindungan yang sifatnya tidak sekedar adaptif dan fleksibel, melaikan juga predektif dan antipatif. 8 Perlindungan hukum merupakan gambaran dari bekerjanya fungsi hukum untuk mewujudkan tujuan-tujuan hukum, yakni keadilan, kemanfaatan dan kepastian hukum. Perlindungan hukum adalah suatu perlindungan yang diberikan kepada subyek hukum sesuai dengan aturan hukum, baik itu yang bersifat preventif maupun dalam bentuk yang bersifat represif, baik yang secara tertulis maupun tidak tertulis dalam rangka menegakkan peraturan hukum. Hakekatnya setiap orang berhak mendapatkan perlindungan dari hukum. Hampir seluruh hubungan hukum harus mendapat perlindungan dari hukum. Oleh karena itu terdapat banyak macam perlindungan hukum.

\section{b. Teori Tanggung Jawab Negara}

Menurut Lawrence Oppenheim, sering dikatakan bahwa negara, sebagai subyek yang berdaulat, tidak dapat dibebani pertanggungjawaban. Pandangan ini hanya benar apabila dikaitkan dengan tindakan-tindakan negara terhadap

${ }^{6}$ Satijipto Raharjo, "Ilmu Hukum”, (Bandung: PT. Citra Aditya Bakti, 2000) hal. 53.

${ }^{7}$ Ibid., hal. 54.

${ }^{8}$ Pillipus M. Hadjon, :Perlindungan Hukum bagi Rakyat Indonesia”, (Surabaya: PT. Bina Ilmu, 1987), hal. 2. 
warganya. ${ }^{9}$ Posisi ini berbeda dalam hubungan suatu negara dengan negara lain. Dalam hal ini negara berkedudukan sebagai subyek hukum International (International Person), dan memiliki pertanggungjawaban yang melekat pada dirinya. Pertanggungjawabannya dalam arti hukum. ${ }^{10}$

Prinsip-prinsip tentang tanggung jawab merupakan perihal yang sangat penting dalam hukum hak asasi manuisa, perlindungan dan penegakan hak asasi manusia. Dalam kasuskasus pelanggaran hak asasi manusia, diperlukan kehati-hatian dalam mengananlisis siapa yang bertanggung jawab dan seberapa jauh tanggung jawab yang dibebankan kepada pihak tertentu. $^{11}$

Tanggung Jawab ada yang menyebutnya: "tanggung gugat". istilah itu dari kata "Liability", menurut Agnes. M. Toar, tanggung jawab sering diartikan "Responsibility". ${ }^{12}$

Alasan menggunakan teori tanggung jawab negara dalam kaitannya dengan persoalan di atas adalah dalam pemenuhan hak atas pekerjaan sering terjadi ketimpangan-ketimpangan yang bersipat sangat prinsipil. Ketimpangan-ketimpangan dimaksud tidak hanya persoalan kebijakan yang tidak berpihak pada kepentingan tenaga kerja yang bersifat perlindungan, kepastian tetapi persoalan lebih pada mengatasi persoalan secara parsial yaitu ledakan jumlah tenaga kerja sehingga perspektif yang dibangun bahwa tenaga kerja ada komoditas yang menguntungkan dan bersifat provit oriented. Ketika persoalan penempatan tenaga keluar negeri muncul, masyarakat bertanya siapa yang bertanggung jawab? Kondisi ini lebih memprihatinkan ketika ada kasus kekerasan terhadap tenaga kerja wanita dan keluarganya, pemerintah seringkali terkesan mengabaikan.

\section{Teori Hak Asasi Manusia}

Secara arfiah HAM adalah hak yang melekat pada diri manusia, bersifat universal dan langgeng, oleh karena itu HAM

\footnotetext{
${ }^{9}$ Hersi Lauterpacht, “Oppeenheim's International Law”, vol 1, Eight Edition, 1995, ham. 336.

${ }^{10}$ Mohamad Mova Al Afghani, Konsep Kealpaan dalam Hukum Pertanggung Jawaban Negara, Skripsi Fakultas Hukum Universitas Indonesia.

${ }^{11}$ Sukarmi, "Tanggung Jawab Pelaku Usaha Atas Kerugian Konsumen Yang Disebabkan Oleh Perjanjan Baku (Standard Contract) Dalam Transaksi Elektronik", (Bandung: Program Pasca sarjana Universitas Padjadjaran Bandung, 2005), hal. 166.

12 Agnes M. Toar 17-29 Juli 1989, Tanggung Jawab Produk dan sejarah Perkembangannya di Beberapa Negara, Makalah dibawakan dalam Penataran Hukum Perikatan II, Ujung Pandang, hlm 1.(dalam Muhamad Naufal Apriyanto, Ringkasan Tesis Tanggung Jawab Negara Terhadap Korban Kekerasan Berbasis Isu Agama Menurut Konstitusi HAM ( Analisis Terhadap Kasus Insiden Monas Berdaarah), hal. 12. 2010 FH UB.
} 
harus dihormati, dilindungi dan dipenuhi, tidak ada suatu kuasa apapun yang dapat mengurangi, merampas serta menagabaikan nya. Hak asasi manusia adalah hak-hak yang dimiliki manusia semata-mata karena ia manusia. Ramdon Naning menyebutkan, " hak asasi manusia ialah hak yang dimiliki oleh seseorang karena orang itu adalah manusia. ${ }^{13}$

Umat manusia memilikinya bukan karena diberikan kepadanya oleh masyarakat atau berdasarkan hukum positif, melainkan semata-mata berdasarkan martabatnya sebagai manusia. $^{14}$

Menurut Suhardi, HAM adalah hak yang melekat pada pribadi manusia sejak manusia sejak manusia dilahirkan untuk mempertahankan martabat manusia dan nilai kemanusiaannya (human worth and dignity) yang tidak mengenal pengotakan ras, bangsa, agama, derajat serta kedudukan. HAM inherent dengan kodrat manusia, merupakan keleluasaan atau kebebasa-kebebasan manusia yang diterima dan dihargai sebagai nilai-nilai sosial yang masing-masing dan bersama-sama mutlak dibutuhkan untuk perwujudan realitas manusi, yaitu seali-aslinya seperti yang digariskan Tuhan. ${ }^{15}$

\section{Landasan Konseptual}

Calon Tenaga Kerja Indonesia yang selanjutnya disebut calon TKI adalah setiap warga negara Indonesia yang memenuhi syarat sebagai pencari kerja yang akan bekerja di luar negeri dan terdaftar di instansi pemerintah kabupaten/kota yang bertanggung jawab di bidang ketenagakerjaan.

Tenaga Kerja Indonesia yang selanjutnya disingkat TKI adalah setiap warga negara Indonesia yang memenuhi syarat untuk bekerja di luar negeri dalam hubungan kerja untuk jangka waktu tertentu dengan menerima upah. TKI Perseorangan adalah TKI yang bekerja pada pengguna berbadan hukum.

\section{a. Penempatan TKI}

Penempatan TKI adalah kegiatan pelayanan untuk mempertemukan TKI sesuai bakat, minat dan kemampuannya dengan pemberi kerja di luar negeri yang meliputi keseluruhan proses perekrutan, pengurusan dokumen, pendidikan dan pelatihan, penampungan, persiapan pemberangkatan,

\footnotetext{
${ }^{13}$ Random Naning, dalam Abdurahman, Op. Cit., hal. 112-113 .

${ }^{14}$ Jack Donnely, “Hukum HAM”, (PUSHAM UII, Jogjakarta, 2008), hal. 11.

${ }^{15}$ Suhardi, dalam Mukti fajar, "Tipe Negara Hukum”, (Malang, Banyumedia Publishing, 2005), hal. 44
} 
pemberangkatan sampai ke negara penempatan, dan pemulangan dari negara penempatan.

Penempatan tenaga kerja indonesia ke luar negeri merupakan salah satu bentuk upaya pemerintah dalam menanggulangi masalah ketenagakerjaan.

Penempatan tenaga kerja dilaksanakan berdasarkan asas:

a) Terbuka yaitu pemberian informasi kepada pencari kerja secara jelas.antara lain jenis pekerjaan, besarnya upah dan jam kerja. Hal ini diperlukan untuk melindungi pekerja serta untuk menghindari terjadinya perselisihan setelah tenaga kerja ditempatkan.

b) Bebas yaitu tidak ada unsur paksaan maupun unsurunsur kekerasan lainnya.

c) Obyektif yaitu pemberi kerja agar menawarkan pekerjaan yang cocok kepada pencari kerja sesuai dengan kemampuan dan persyaratan jabatan yang dibutuhkan serta harus memperhatikan kepentingan umum dengan tidak memihak kepada kepentingan pihak tertentu.

d) adil dan setara tanpa diskriminasi yaitu penempatan tenaga dilakukan berdasarkan kemampuan tenaga kerja dan tidak didasarkan atas ras,jenis kelamin, warna kulit agama dan aliran politik. ${ }^{16}$

Penempatan tenaga kerja indonesia keluar negeri adalah kegiatan penempatan tenaga kerja yang dilakukan oleh badanbadan tertentu yang telah ditetapkan berdasarkan Undang Undang. Adapun lembaga pelaksana terdiri sebagai berikut;

a) PPTKIS (Perusahaan Pengerah Tenaga Kerja Indonesia Swasta );

b) Instansi Pemerintah atau Badan Usaha milik Negara;

c) Badan usaha swasta untuk kepentingan diri sendiri.

Pelayanan penempatan TKI diluar negeri mencakup:

a) kegiatan penempatan;

b) selama penempatan;

c) sampai penempatan

Pelaksanaan penempatan terbagi dalam tahap-tahap :

a) pra penempatan;

b) masa penempatan;

c) purna penempatan;

${ }^{16}$ Hardijan Rusli, "Hukum Ketenagakerjaan”, (Jakarta: Ghalia Indonesia, 2005), hal. 31. 
d) perpanjangan penempatan.

Pelaksana Penempatan TKI Swasta selanjutnya disingkat PPTKIS adalah badan hukum yang telah memperoleh izin tertulis dari Pemerintah untuk menyelenggarakan pelayanan penempatan TKI di luar negeri.

\section{b. Perlindungan Hukum}

Terkait penempatan TKI Indonesia di luar negeri "Buruh migran Indonesia“" adalah perlindungan yang dapat menjakau keberadaan TKI yang bekerja di luar negeri mulai dari: ${ }^{17}$

a) Perlindungan hukum selama pengerahan, sebelum dam sesudah keberangkatan tenaga kerja wanita;

b) Perlindungan hukum berhubungan dengan pelaksaan perjanjian kerja di luar negeri;

c) Perlindungan hukum buruh migrant Indonesia setelah perjanjian kerja berakhir;

d) Mengacu pada pendapat Soepomo dan Maslan bahwa perlindungan hukum bagi tenaga kerja dapat dibagi menjadi 3 macam:

1) Perlindungan ekonomis yaitu perlindungan tenaga kerja dalam bentuk penghasilan yang cukup termasuk apabila tenaga kerja tidak mampu bekerja diluar kehendaknya

2) Perlindungan sosial yaitu perlindungan tenaga kerja dalam bentuk jaminan kesehatan kerja, kebebasan berserikat dan jaminan hak untuk berorganisasi

3) Perlindungan tehnis yaitu perlindungan tenaga kerja dalam bentuk keamanan dan keselamatannya. ${ }^{18}$

\section{Metode Penelitian}

\section{Jenis Penelitian}

Jenis penelitian hukum ini adalah penelitian hukum normatif. Sebagai ilmu hukum normatif, maka ilmu hukum memiliki cara kerja yang khas dalam membantu memecahkan persoalan hukum yang dihadapi masyarakat. Dalam hal ini ilmu hukum normatif dipahami sebagai ilmu tentang kaidah (norma), merupakan ilmu

\footnotetext{
${ }^{17}$ HLMP Rajagukguk, Perlindungan Hukum Buruh Migran Indonesia, "Majalah Arena Hukum”, No 7 tahun 1999.

${ }^{18}$ Muslan Abdurrahman, “Ke Tidak Patuhan TKI”, (Malang: UMM, 2006), hal, 31.
} 
yang menelaah hukum sebagai kaidah atau sistem kaidah-kaidah, dengan dogmatik hukum atau sistematik hukum. Dengan demikian sebagai penelitian hukum normatif, maka tujuan penelitian ini adalah untuk mengetahui, mengkaji dan memahami asas-asas hukum, norma-norma hukum dan kebijakan-kebijakan serta sinkronisasi aturan hukum di bidang penataan ruang.

Penelitian hukum normatif menurut Mukti Fajar dan Yulianto Achmad $^{19}$ "adalah penelitian hukum yang meletakkan hukum sebagai sebuah bangunan sistem norma. Sistem norma yang dimaksud adalah mengenai asas-asas, norma-norma, kaidah-kaidah dari peraturan perundang-undangan, putusan pengadilan, perjanjian serta doktrin (ajaran)".

\section{Metode Pendekatan}

Adapun metode pendekatan yang digunakan dalam penelitian hukum normatif iniadalah pendekatan perundang-undangan (statute approach), pendekatan konsep (conceptual approach), dan pendekatan komparatif (compartive approach).

\section{Sumber dan Jenis Bahan Hukum}

Sumber bahan hukum dalam penelitian hukum normatif ini adalah bahan kepustakaan (liberary reseach),dengan jenis bahan hukum, yaitu bahan hukum primer berupa Undang-Undang, Peraturan Pemerintah, Peraturan Presiden, Peraturan Daerah, dan lainnya, bahan-bahan hukum sekunder berupa: konsep-konsep teori dan pendapat para ahli hukum, dan dokumen-dokumen resmi, hasil-hasil penelitian, serta bahan hukum tertier berupa kamuskamus bahasa dan kamus hukum. ${ }^{20}$ Bahan-bahan hukum inilah yang dikaji dan dianalisis mengenai sinkronisasinya.

\section{Teknik Pengumpulan Bahan Hukum}

Mengingat sumber bahan hukumnya adalah bahan kepustakaan maka, pengumpulan bahan hukum dilakukan dengan mengkaji dan menganalisis bahan-bahan kepustakaan yaitu mengkaji Undangundang dan peraturan-peraturan, dan pendapat-pendapat para ahli hukum yang berkaitan dengan penelitian ini. Selain itu juga mengkaji dokumen-dokumen resmi negara, hasil-hasil penelitian hukum sebelumnya, kamus hukum dan ensiklopedia hukum.

\footnotetext{
${ }^{19}$ Mukti Fajar ND dan Yulianto Achmad, "Dualisme Penelitian Hukum, Normatif dan Empiris:, (Yogyakarta: Pustaka Pelajar, Cet. I, 2010), hal. 34.

${ }^{20}$ Soerjono Soekanto, "Pengantar Penelitian Hukum", (Jakarta, UI Press, 1986), hal. 12.
} 


\section{Teknik Analisis Bahan hukum}

Untuk mengkaji hukum dari aspek normatif (law in book), maka metode normatif analitislah yang dijadikan acuan dalam mengkaji dan menganalis sesuatu permasalahan. Penelitian normatif pada ranah filosofis mendialogkan secara eksploratif asasasas, nilai-nilai mengenai keadilan dan kepastian. Dengan demikian, analisis bahan hukum dengan cara menggunakan penafsiran-penafsiran hukum, baik penafsiran otentik, penafsiran gramatikal, penafsiran historikal, maupun penafsiran secara ekstensif. $^{21}$

Dari hasil analisis selanjutnya mencari prinsip-prinsip hukum, hubungan-hubungan antara prinsip hukum yang satu dengan prinsip hukum lainnya, persamaan hal-hal yang sering timbul, dan sebagainya kemudian disimpulkan dengan menggunakan penalaran deduktif-induktif.

\section{Pembahasan}

Pengaturan Perlindungan hukum terhadap buruh migran di tinjau dari International Convention on the Protection of the Human Rights of All Migrant Workers and Member of Their Families

1. Tinjauan umum International Convention on the Protection of the Rights of All Migrant Workers and Members of Their Families (Konvensi Internasional mengenai Perlindungan Hak-Hak Seluruh Pekerja Migran dan Anggota Keluarganya).

Pada tanggal 18 Desember 1990 Majelis Umum Perserikatan Bangsa-Bangsa telah mengeluarkan Resolusi Nomor $\mathrm{A} / \mathrm{RES} / 45 / 158$ mengenai International Convention on the Protection of the Rights of All Migrant Workers and Members of Their Families (Konvensi Internasional mengenai Perlindungan Hak-Hak Seluruh Pekerja Migran dan Anggota Keluarganya). Resolusi tersebut memuat seluruh hak-hak pekerja migran dan anggota keluarganya dan menyatakan akan mengambil langkahlangkah untuk menjamin pelaksanaan Konvensi ini. Pada tanggal 22 September 2004 di New York, Pemerintah Indonesia telah menandatangani International Convention on the Protection of the Rights of All Migrant Workers and Members of Their Families (Konvensi Internasional mengenai Perlindungan Hak-Hak Seluruh Pekerja Migran dan Anggota Keluarganya) tanpa reservasi.

${ }^{21}$ S. Nasution, "Metode Penelitian Naturalistik”, (Bandung, Transito, 1982), hal. 129. 
Penandatanganan tersebut menunjukkan kesungguhan Negara Indonesia untuk melindungi, menghormati, memajukan dan memenuhi hak-hak seluruh pekerja migran dan anggota keluarganya, yang pada akhirnya diharapkan dapat memenuhi kesejahteraan para pekerja migran dan anggota keluarganya. Sebagai salah satu negara yang telah menandatangani International Convention on the Protection of the Rights of All Migrant Workers and Members of Their Families (Konvensi Internasional mengenai Perlindungan Hak-Hak Seluruh Pekerja Migran dan Anggota Keluarganya), Indonesia memiliki komitmen untuk meratifikasi Konvensi ini. Ratifikasi Konvensi ini diharapkan dapat mendorong terciptanya ratifikasi universal dan penerapan prinsip serta norma standar internasional bagi perlindungan hak-hak seluruh pekerja migran dan anggota keluarganya secara global.

International Convention on the Protection of the Human Rights of All Migrant Workers and Member of Their Families merupakan konvensi internasional yang komprehensif, yang focus pada perlindungan hak-hak buruh migran dan memastikan bahwa hak-hak tersebut dilindungi dan dihormati, berlaku pada 1 Juli 2003 dan hingga Januari 2010 negara yang meratifikasi berjumlah 42 negara. Berlakunya konvensi ini telah memperkuat dan melengkapi serangkaian ketentuan-ketentuan mengenai perjanjian hak asasi manusia yang dikeluarkan oleh Perserikatan Bangsa-Bangsa (PBB). Konvensi ini menetapkan standar minimum yang harus diterapkan negara pihak pada buruh migran dan anggota keluarganya, terlepas dari status migrasi mereka, yang terdiri dari beberapa bagian sebagai berikut:

a) Bagian I tentang ruang lingkup dan definisi (Pasal 1-Pasal 6);

b) Bagian II tentang non-diskriminasi dalam kaitannya dengan hak (Pasal 7);

c) Bab III tentang hak azasi bagi semua buruh migran dan anggota keluarganya (Pasal 8-Pasal 5);

d) Bagian IV tentang hak lain dari buruh migran dan anggota keluarganya yang didokumentasikan atau yang berada dalam situasi normal (Pasal 36-Pasal 56);

e) Bagian $\mathrm{V}$ tentang ketentuan yang berlaku bagi golongan tertentu buruh migrant dan anggota keluarganya (Pasal 57Pasal 63) f. Bagian VI tentang memajukan kondisi yang baik, setara, manusiawi dan sah sehubungan dengan migrasi internasional dari buruh dan anggota-anggota keluarganya (Pasal 64-pasal 71);

f) Bagian VII tentang penerapan konvensi (Pasal 72-Pasal 78) h. Bagian VIII tentang ketentuan umum (Pasal 79Pasal 84);

g) Bagian IX tentang ketentuan penutup (Pasal 85-Pasal 93). 
Perlindungan hukum yang diberikan terhadap buruh migran menurut hukum internasional tertuang dalam International on The Protection of Human Rights of All Migran Workers And Member of Their Family. Sedangkan dalam peraturan perundang-undangan nasional, perlindungan hukum terhadap buruh migrant tertuang dalam Undang-Undang Nomor 13 Tahun 2003 tentang Ketenagakerjaan, Undang-Undang Nomor 39 Tahun 2004 tentang Penempatan dan Perlindungan Tenaga Kerja Indonesia di Luar Negeri, Undang-Undang Nomor 37 Tahun 1999 tentang Hubungan Luar Negeri dan Undang-Undang Nomor 39 Tahun 1999 tentang Hak Asasi Manusia. Secara khusus, Konvensi Internasional mengenai Perlindungan Hak-hak Seluruh Pekerja migran dan Anggota Keluarganya dapat digunakan sebagai alat untuk mempromosikan pendekatan terhadap migrasi berbasis hak asasi, baik dalam pengembangan kebijakan migrasi nasional maupun dalam proses bilateral atau multilateral berkenaan dengan migrasi. Konvensi Internasional mengenai Perlindungan Hak-Hak Seluruh Pekerja Migran dan Anggota Keluarganya (International Convention on the Protection of the Rights of All Migrant Workers and Members of Their Families, ICRMW) 1990 merupakan kerangka paling luas dalam hukum internasional bagi perlindungan hak-hak pekerja migran dan anggota keluarganya dan petunjuk bagi negara megenai bagaimana cara mengembangkan kebijakan migrasi tenaga kerja sembari menghormati hak-hak migran.

\section{Perlindungan Hak Asasi Pekerja Migran dan Anggota Keluarganya}

Konvensi Perlindungan Hak-Hak Seluruh Pekerja Migran dan Anggota Keluarganya (International Convention on the Protection of the Rights of All Migrant Workers and Members of Their Families, ICRMW) mendefinisikan hak-hak pekerja migran di bawah dua tajuk utama: hak asasi seluruh pekerja migran dan anggota keluarganya (Bagian III), dan hak-hak lain pekerja migran dan anggota keluarganya yang berdokumen atau legal (Bagian IV). Hak asasi berlaku pada seluruh pekerja migran dan anggota keluarganya tanpa memandang status hukum mereka, sementara hak-hak lain berlaku hanya pada pekerja migran dan anggota keluarganya yang berdokumen. Konvensi tersebut tidak mencantumkan serangkaian hak-hak baru yang secara eksklusif bagi pekerja migran dan anggota keluarganya. Namun, sebagian besar hak yang termaktub di dalam Konvensi tersebut, misalnya, banyak pasal di Bagian III, menyatakan ulang dan menekankan pemberlakuan untuk pekerja migran dan anggota keluarganya hak- 
hak relevanyang dicantumkan di dalam Kovenan Internasional mengenai Hak Sipil dan Hak Politik dan Kovenan Internasional mengenai Hak Ekonomi, Hak Sosial dan Hak Budaya dan perjanjianperjanjian hak asasi utama lainnya. Namun Konvensi tersebut mencantumkan sejumlah hak yang membutuhkan perlindungan khusus dan memberikan jaminan tambahan mengingat kerentanan khusus pekerja migran dan anggota keluarganya, hak-hak itu secara garis besar dapat diuraikan sebagai berikut:

\section{a. Hak-hak dan Kebebasan Dasar}

Konvensi tersebut mempertahankan hak yang telah mapan untuk semua, termasuk pekerja migran, untuk meninggalkan sebuah negara dan masuk serta tinggal di negara asal mereka (Pasal 8), tanpa memandang status migrasi mereka. Kondisi hidup dan kerja yang tidak manusiawi serta pelecehan fisik (dan seksual) yang kadang-kadang dialami oleh pekerja migran ditangani dengan menegaskan ulang hak mereka atas kehidupan (Pasal 9) dan pelarangan perlakuan atau hukuman yang kejam, tidak manusiawi atau merendahkan (Pasal 10), perbudakan atau kerja paksa atau kerja wajib (Pasal 11), serta dengan kewajiban negara melindungi pekerja migran dan anggota keluarganya dari kekerasan, cedera fisik, ancaman dan intimidasi (Pasal 16, para. 2).

Seluruh pekerja migran dan anggota keluarganya juga berhak atas kebebasan dasar seperti kebebasan berpikir, berpendapat dan beragama (Pasal 12), dan hak untuk memiliki dan mengungkapkan pendapat (Pasal 13). Mereka tidak boleh dicampuri privasi, keluarga, rumahtangga, korespondensi atau komunikasi mereka lainnya secara sewenang-wenang atau secaratidak sah atau mendapatkan serangan tidak sah terhadap kehormatan dan nama baik mereka (Pasal 14). Harta benda mereka tidak boleh dirampas secara sewenang-wenang (Pasal 15). Tiap anak seorang pekerja migran harus memiliki hak atas nama, pendaftaran kelahiran dankebangsaan (Pasal 29).

\section{b. Proses Hukum yang Semestinya dalam Migrasi}

Konvensi tersebut menjelaskan secara detail perlunya menjamin adanya proses yang semestinya bagi seluruh pekerja migran dan anggota (Pasal 16 - 20). Penyelidikan, penangkapan dan penahanan harus dilakukan sesuai dengan prosedur yang ada. Jika ditangkap, pekerja migran harus diinformasikan dengan menggunakan bahasa yang mereka pahami mengenai alasan penahanan tersebut. Hak atas persamaan dengan warga lokal Negara di depan pengadilan dan 
sidang pemeriksaan harus dihormati. Jika dituduh melakukan kejahatan pidana, migran harus diberi penasehat hukum yang diperlukan dan bantuan penerjemah gratis jika diperlukan. Bila dijatuhi hukuman, pertimbangan kemanusiaan mengenai status migran orang tersebut harus dipertimbangkan. Pengusiran sewenang-wenang atau pengusiran kolektif terhadap pekerja migran dilarang (Pasal 22).

\section{c. Perlindungan Consular}

Perwakilan konsular atau diplomatik negara asal sang migran harus diberitahu dengan segera mengenai penahanan migran tersebut, jika dia memintanya, dan migran tersebut memiliki hak untuk berkomunikasi dengan otoritas ini (Pasal 16, para. 7). Seluruh migran harus memilikihak atas perlindungan dan asistensi otoritas konsular atau otoritas diplomatik negara termasukdalam kasus pengusiran (Pasal 23).

\section{d. Kesetaraan dengan Warga Lokal}

Seluruh pekerja migran harus diperlakukan sama dengan warga lokal negara tempat kerja dalam hal pengupahan dan syarat kerja [waktu lembur, jam kerja, libur mingguan, harihari libur dengan tetap dibayar, keselamatan, kesehatan, pemutusan kontrak kerja, usia minimum, batasan pekerjaan rumah tangga, dan lain-lain. (Pasal 25)]. Mereka berhak bergabung dengan suatu serikat atau asosiasi pekerja, dan turut serta dalam pertemuan dan aktivitasnya (Pasal 26). Kesetaraan dengan warga lokal juga meluas pada perawatan medis darurat (Pasal 28) dan jaminan sosial (Pasal 27), meskipun bukan tidak penting bahwa Konvensi tersebut mengkaitkan hak atas jaminan sosial dengan terpenuhinya persyaratan yang mungkin ada di perundang-undangan domestik dan perjanjian bilateral dan multilateral yang berlaku. Anak-anak seorang pekerja migran memiliki hak untuk mengakses pendidikan atas dasar persamaan perlakuan dengan warga lokal negara bersangkutan (Pasal 30).

\section{e. Perampasan Dokumen Identitas}

Konvensi tersebut melarang praktek perampasan paspor pekerja migran oleh pengusaha dan dengan jelas menyatakan bahwa hanya pejabat publik yang benar-benar disahkan oleh hukumlah yang diizinkan melakukan perampasan dan penghancuran dokumen identitas, izin masuk, izin tinggal atau izin kerja (Pasal 21). 


\section{f. Pengiriman Penghasilan}

Hingga berakhir masa tinggal di negara tempat bekerja, seluruh pekerja migran dan anggota keluarganya berhak mengirimkan penghasilan dan tabungannya serta harta benda pribadi mereka (Pasal 32).

\section{g. Hak atas Informasi}

Pekerja migran dan anggota keluarganya berhak mendapatkan informasi dari negara asal, negara transit dan negara tempat bekerja mengenai hak yang muncul dari Konvensi ini serta syarat-syarat penerimaan mereka, dan hakhak serta kewajiban mereka di negara-negara tersebut. Informasi semacam itu harus disediakan bagi pekerja migran secara gratis dan menggunakan bahasa yang dipahami oleh mereka (Pasal 33).

\section{h. Penghargaan Terhadap Identitas Budaya}

Negara peratifikasi harus menjamin dihargainya identitas budaya seluruh pekerja migran dan anggota keluarganya dan tidak diperkenankan mencegah mereka menjaga kaitan budaya dengan negara asal mereka (Pasal 31). Negara peratifikasi juga harus menghormati kebebasan pendidikan keagamaan dan moral yang diberikan oleh orang tua kepada anak-anaknya sesuaidengan keyakinan mereka sendiri (Pasal 12, para. 4).

\section{i. Kewajiban Mematuhi Hukum Lokal}

Seluruh pekerja migran dan anggota keluarganya berkewajiban mematuhi undang-undang dan peraturan negara transit atau negara tempat bekerja serta berkewajiban menghargai identitasbudaya penduduknya (Pasal 34).

\section{Hak-hak lain Pekerja Migran dan Anggota Keluarganya yang berdokumen}

Konvensi Perlindungan pekerja migran dan anggota keluarganya juga mengakui hak-hak lain yang lebih penuh bagi pekerja migran dan anggota keluarganya yang berdokumen. Diantaranya adalah:

\section{a. Kebebasan Bergerak}

Pekerja migran dan anggota keluarganya yang berdokumen berhak atas kebebasan bergerak di wilayah negara 
tempat bekerja dan juga kebebasan memilih tempat tinggal (Pasal 39).

\section{b. Persamaan Perlakuan dengan Warga Lokal}

Selain di bidang-bidang yang disebutkan di Pasal 25, pekerja migran dan anggota keluarganya yang berdokumen haruslah menikmati kesetaraan dengan warga lokal negara tempat bekerja di bidang-bidang berikut: akses kepada pendidikan, petunjuk lapangan kerja dan layanan penempatan; pelatihan kerja dan pelatihan ulang; akses kepada perumahan termasuk skema perumahan sosial dan perlindungan terhadap eksploitasi berkenaan dengan sewa; akses kepada layanan sosial dan kesehatan; akses kepada koperasi dan perusahaan mandiri; akses kepada dan partisipasi dalam kehidupan budaya (Pasal 43). Anggota keluarga pekerja migran yang berdokumen juga harus menikmati kesetaraan dengan warga lokal negara tempat kerja dalam hal akses kepada lembaga dan layanan pendidikan, lembaga dan layanan petunjuk dan pelatihan kerja, layanan sosial dan kesehatandan partisipasi dalam kehidupan budaya (Pasal 45). Negara tempat bekerja harus membuat kebijakan yang bertujuan memfasilitasi integrasi anak-anak di dalam sistem sekolah lokal, terutama dalam hal mengajar mereka bahasa lokal (Pasal 45(2)). Negara tempat bekerja bias juga menyediakan skema pendidikan khusus dalam bahasa ibu anak-anak pekerja migrant (Pasal 45(4)), bila perlu bekerjasama dengan negara asal.

Pekerja migran dan anggota keluarganya yang berdokumen tidak boleh dibebani pajak atau biaya yang lebih tinggi atau lebih berat dari pada yang dibebankan kepada warga lokal dalam keadaan yang sama dan harus berhak atas pengurangan atau pembebasan dari pajak atau tunjangan pajak yang berlaku pada warga lokal dalam keadaan yang sama (Pasal 48). Pekerja migran dan anggota keluarganya yang berdokumen harus mendapatkan perlakuan yang sama dengan warga lokal negara tempat bekerja dalam hal perlindungan terhadap pemecatan, tunjangan tidak bekerja, akses kepada skema kerja publik yang dimaksudkan untuk menghapuskan pengangguran dan akses kepada pekerjaan alternatif bila kehilangan pekerjaan atau diputuskan dari aktivitas berbayar lainnya (Pasal 54).

\section{c. Hak-hak Lain}

Pekerja migran dan anggota keluarganya yang berdokumen berhak mendapatkan informasi selengkapnya, paling lambat pada penerimaan mereka masuk ke negara 
tempat kerja, mengenai semua syarat yang berlaku untuk penerimaan mereka dan terutama syarat-syarat terkait tinggal mereka dan aktivitas berbayar yang mungkin mereka jalani (Pasal 37). Negara tempat bekerja harus berupaya keras memberi kewenangan pekerja migran berdokumen untuk secara temporer absen tanpa ada dampak terhadap keabsahan mereka tinggal dan bekerja (Pasal 38).

Pekerja migran dan anggota keluarganya yang berdokumen juga berhak membentuk asosiasi atau serikat pekerja di negara tempat bekerja (Pasal 40). Mereka berhak berpartisipasi di dalam urusan publik negara asal mereka dan berhak memilih dan dipilih di dalam pemilihan umum negara itu sesuai dengan undang-undangnya (Pasal 41). Negara-negara harus mempertimbangkan untuk membuat prosedur atau lembaga untuk tujuan mempertimbangkan kebutuhan, aspirasi dan kewajiban khusus pekerja migran dan anggota keluarganya. Pekerja migran harus memiliki perwakilan yang mereka pilih secara bebas di dalam lembaga ini (Pasal 42). Migran berhak atas perlindungan atas kebersamaan keluarga mereka, dan negara harus melakukan langkah-langkah "yang dianggap perlu" untuk memfasilitasi penyatuan/reunifikasi keluarga bagi pekerja migran yang berdokumen dan anggota keluarganya (Pasal 44). Mereka mendapatkan pembebasan biaya impor dan ekspor berkenaan dengan barang-barang pribadi dan rumah tangga serta peralatan kerja mereka (Pasal 46). Pekerja migran berdokumen juga berhak mengirim uang dan negara harus melakukan langkah-langkah yang diperlukan untuk memfasilitasi pengiriman tersebut (Pasal 47). Bila kontrak kerja dilanggar oleh sang pengusaha, pekerja migran berhak mengadukan kasusnya kepada pihak berwenang di Negara tempat bekerja (Pasal 54 (d).

\section{Penutup}

\section{Simpulan}

Konvensi Perlindungan Hak-Hak Seluruh Pekerja Migran dan Anggota Keluarganya (International Convention on the Protection of the Rights of All Migrant Workers and Members of Their Families, ICRMW) mendefinisikan hak-hak pekerja migran di bawah dua tajuk utama: hak asasi seluruh pekerja migran dan anggota keluarganya (Bagian III), dan hak-hak lain pekerja migran dan anggota keluarganya yang berdokumen atau legal (Bagian IV). Hak asasi berlaku pada seluruh pekerja migran dan anggota keluarganya tanpa memandang status hukum mereka, sementara hak-hak lain berlaku hanya pada pekerja migran dan anggota 
keluarganya yang berdokumen. Konvensi tersebut tidak mencantumkan serangkaian hak-hak baru yang secara eksklusif bagi pekerja migran dan anggota keluarganya.

\section{Rekomendasi}

Hendaknya UU No 6 Tahun 2012 tentang Pengesahan tentang Konvensi Perlindungan Hak-Hak Seluruh Pekerja Migran dan Anggota Keluarganya disosialisasikan kepada seluruh masyarakat agar masyarakat khususnya tenaga kerja wanita memahami perlindungan yang akan diberikan selam bekerja di Luar negeri. 


\section{Daftar Pustaka}

Abdurahman. Ilmu Hukum, Teori Hukum dan Ilmu Perundang-undangan, Bandung: Citra Aditya Bakti, 1995.

Abdurrahman, MuslanUMM, Ke Tidak Patuhan TKI, 2006.

Al Afghani, Mohamad Mova. Konsep Kealpaan dalam Hukum Pertanggung Jawaban Negara, Skripsi Fakultas Hukum Uiniversitas Indonesia, 2003.

Brugink, JJ. Refleksi Tentang Ilmu Hukum, Alih Bahasa oleh Arif Sidharta, Bandung .PT. Citra Aditya Bakti, 1996.

Donnely, Jack. Hukum HAM, PUSHAM UII, Jogjakarta, 2008.

Husni, Lalu. Pengantar Hukum Ketenagakerjaan Indonesia, Raja Grafindo Persada, Jakarta, 2000.

Lauterpacht, Hersi. Oppeenheim's International Law, vol 1, Eight Edition, 1995.

Mertokusumo, Sudikno. Penemuan Hukum-Sebuah Pengantar, Yogyakarta, Liberty, 2001.

Mukti Fajar ND. dan Yulianto Achmad, Dualisme Penelitian Hukum, Normatif dan Empiris, Yogyakarta, Pustaka Pelajar, Cet. I, 2010.

Radbruch, dalam W. Friedmann. Legal Teory, London: Steven \& Sons, 1958 .

Rahardjo, Satipto. Ilmu Hukum, Bandung, Citra Aditya Bakti, 2000.

Soekanto, Soerjono. Pengantar Penelitian Hukum, Jakarta, UI Press, 1986.

Sukarmi, Tanggung Jawab Pelaku Usaha Atas Kerugian Konsumen Yang Disebabkan Oleh Perjanjan Baku (Standard Contract) Dalam Transaksi Elektronik, Program Pascasarjana Universitas Padjadjaran Bandung, 2005.

Wignjosoebroto, Soetandyo. Hukum-Paradigma, Metode dan Dinamika Masalahnya, Jakarta, Elsam dan Huma, 2002.

\section{Artikel /Jurnal.}

Agnes M. Toar 17-29 Juli 1989, Tanggung Jawab Produk dan sejarah Perkembangannya di Beberapa Negara, Makalah dibawakan dalam Penataran Hukum Perikatan II, Ujung Pandang, hlm 1.(dalam Muhamad Naufal Apriyanto, Ringkasan Tesis Tanggung Jawab Negara Terhadap Korban Kekerasan Berbasis Isu Agama Menurut Konstitusi HAM (Analisis Terhadap Kasus Insiden Monas Berdaarah) 2010 FH UB. 
Majalah Tenaga Kerja, Sistem Penempatan Tenaga Kerja Indonesia ke Luar Negeri, Vol 37, 2009.

KOMNAS HAM, Pembangunan Berbasis Hak Asasi Manusia: Sebuah Panduan, Kerjasama antara KOMNAS HAM dengan Australian Government, AUS AID, 2007.

Rajagukguk, HLMP. Perlindungan Hukum Buruh Migran Indonesia, Dalam Majalah Arena Hukum No. 7 tahun 1999.

\section{Internet}

$<$ http//bnp2tki.go.id>

Eddy, Arini Titis. "Ide Kontemvorer Tentanz Hak Asasi Manusia", <http://www.usembassriakarta.org/p /hakasasil-3.html>. Diakses pada 1 Maret 2015.

Pigay, Natalis. "TKI dan Tuntutan Globalisasi", <http://www.nakertrans.go.id/arsipberita/naker/tkiglobalisasi.php>. Diakses pada tangga119 Juni 2015.

Rawls, John. "A Theory of Justice" (Cambridge, Mass: Harvard University Press, 1971). 